\title{
ナノDDS 製剤の分析評価技術一総括一
}

\author{
加藤くみ子 \\ Overview of Analytical Techniques for Evaluation of Nano-DDS Formulations \\ Kumiko Sakai-Kato \\ Division of Drugs, National Institute of Health Sciences; 3-25-26 Tanomachi, \\ Kawasaki-ku, Kawasaki 210-9501, Japan.
}

(Received August 6, 2018)

\begin{abstract}
Nanotechnology-based formulations have attracted much attention as delivery tools for a variety of payloads. These payloads include oligonucleotides, peptides, and low-molecular weight chemical entities. Guidelines and reflection papers for nanotechnology-based drug products have been published by the Japanese Ministry of Health, Labour, and Welfare. These documents include the concept of quality by design (QbD) approach, as described in the International Council for Harmonisation of Technical Requirements for Pharmaceuticals for Human Use (ICH) guidelines. The quality attributes that affect efficacy and safety of nanotechnology-based drug products should be identified to establish the entire picture of the drug products. Hence it is essential to develop analytical methods for characterizing these attributes. Furthermore, to evaluate the comparability of nano-drug delivery system (DDS) formulations before and after changes to their manufacturing process, it is desirable to characterize the key attributes using more than one analytical method for each. Standardization of these analytical methods is underway. This paper provides an overview of the concept and significance of the QbD approach for nano-DDS formulations, guidelines for the development of nano-DDS formulations, and standardization of analytical methods for nano-DDS formulations.
\end{abstract}

Key words_ nano-drug delivery system formulation; quality by design; analytical technique; standardization

\section{1. はじめに}

ナノテクノロジーを応用した drug delivery system (DDS) 製剤（以下，ナノ DDS 製剂と称する）に は，ナノエマルジョン，ナノスフェア，リポソー ム，高分子に薬物を結合させた製剤があり，わが国 でも複数の製剤が承認されている. 1) 1988 年には, わが国発のナノエマルジョン製剤が承認され，既に 後発品も登場している。 また, 含糖酸化鉄注射液で あるナノスフェア製剤も国内で開発された製剤であ る.

ナノサイズのキャリアに有効成分を封じ込むこと による製剤学的機能には, 有効成分の安定性向上, バイオアベイラビリティーの向上, 放出制御, 標的 性機能の付与等がある. 特に, 近年では, オリゴ核 酸である siRNA のように, 生体内での安定性向上

国立医薬品食品衛生研究所薬品部（干210-9501 川崎市 川崎区殿町 3-25-26)

e-mail: kumikato@nihs.go.jp

本総説は, 日本薬学会第 138 年会シンポジウムS59 で

発表した内容を中心に記述したものである.
や細胞内への薬物送達を目的とした膜透過性向上の 手段としてナノ DDS 製剤が注目されている. ${ }^{2)}$ 筆 者は，その実用化促進のためにナノDDS 製剂のレ ギュラトリーサイエンス研究に取り組んでいる. 本 稿では，ライフサイクルを通じた品質確保に資する 製剂開発アプローチについて紹介し，その概念を取 り入れたナノDDS 製剂関連のガイドラインの紹 介, さらに，ライフサイクルを通じた品質システム の構築を支える品質特性分析法の標準化について述 ベ, 誌上シンポジウムの総括としたい.

2. ナノ DDS 製剂開発へのクオリティーバイデ ザイン（quality by design; QbD）アプローチの適用

医薬品開発においては，適正な品質を有する製品 を設計すること，及び意困した機能を有する製品を 一貫して供給できる製造工程を設計することが重要 である、製剤開発研究や製造経験を通して得られた 情報や知識により科学的理解が深まり，これが製造 工程管理や規格の確立に役立つ。さらに製剤開発か ら得られた情報を品質リスクマネージメントの基盤 とすることが可能である. ${ }^{3)}$ 
昨今，このようなライフサイクルを通じた品質確 保のため科学的体系的アプローチ（QbD アプロー チ）の取り組みが医薬品開発に求められており, ${ }^{3}$ 機能性製剂の代表であるナノDDS 製剂についても このような管理戦略を構築することが望まれる。し かし，一般的な医薬品とは異なり，製剂特性や製造 工程が複雑であり，また製剤特性や製造工程が製品 毎に大きく異なると考えられ，QbD アプローチの 例示は限られていた。 そこで，筆者らは，乳酸・グ リコール酸共重合体ナノ粒子をモデルとして， QbD アプローチの実践を試みた. ${ }^{4)}$ 具体的には製品 特性に係わる重要品質特性 (critical quality attributes；CQA）と重要プロセスパラメータ（critical process parameter；CPP）の相関を明らかにするた めに，特性要因図及び分散分析を用いた品質リスク マネージメント (quality risk management; QRM) を行った．処方のスクリーニングを兼ねた比較的初 期の検討における QbD アプローチの実例である が，開発段階におけるナノDDS 製剤においても QbD アプローチの応用が可能と考えられ，今後ナ ノDDS 製剤開発への応用が広がることを期待した い.

\section{3. ナノ DDS 製剤の開発のためのガイドライン} 作成

わが国では，ナノDDS 製剤開発のための指針と して，3 件のガイドラインあるいはリフレクション ペーパーが厚生労働省より発出されている. ${ }^{5-7)}$ そ れぞれ，ブロック共重合体ミセル医薬品，リポソー ム製剂，及び核酸（siRNA）を搭載したナノ製剂を 対象に，開発や評価の際の考慮点を文書化したもの である．内包薬物の適用範囲は，低分子化学合成品 のほか, 核酸, 又はペプチドやタンパク質である.

「核酸（siRNA）搭載ナノ製剤に関するリフレク ションペーパー」は主として siRNA に焦点を当て 作成されたが，他の核酸を搭載する際にも参考とな るであろう。

「リポソーム製剤の開発に関するガイドライン」 には，「製剤全体として製剤設計及び品質特性に対 する評価を行い，管理範囲を設定していく必要があ る。また、リポソーム製剤は製剂学的に複雑であ り，必ずしも最終製品の品質試験のみでは十分に品 質を管理できない場合がある。よって，日米 EU 医 薬品規制調和国際会議（The International Council for Harmonisation of Technical Requirements for Pharmaceuticals for Human Use; ICH） Q8（R2）及 び Q11 ガイドラインに概説されている QbD の考え に基づいた製剤開発を強く推奨する」と明記されて (る. $\left.{ }^{6}\right)$ 具体的には，「重要品質特性及び関連する特 性値を踏まえ，製剤品質の一貫性を保証するための 管理戦略を策定した上で，必要な規格及び試験方法 を決定する」。また，「リポソーム構成成分の選択・ 処方と各成分の機能については, 目標製品品質プロ ファイル及び製剤特性（例えば，放出性，標的指向 性など)への影響と関連付けて記述する」。さらに, 「製剂設計，品質特性（物理的，化学的及び生物学 的特性)，製造工程などの変動が製剂特性にどのよ うに影響するのか，開発段階で行った検討を明らか にし, 必要に応じて薬物動態, 有効性及び安全性に 及ぼす影響についても評価・検討する」ことが重要 である. ${ }^{6}$

米国食品医薬品庁 (U.S. Food and Drug Administration；FDA）からは，2018 年にリポソーム製剤に 関するガイダンスの最終版が公表された。 ${ }^{8)} 2002$ 年 に公表されたドラフトガイダンスは，新薬開発を対 象とした文章であったが，その後，リポソーム製凨 の後発品が米国で承認され, 今回最終化されたガイ ダンスには, Abbreviated New Drug Applications （ANDA）申請を経た製剤，つまりリポソーム製剤 の後発品開発に関する内容も包含されている.

ANDA 申請の際は，FDA から示されている製品特 異的な生物学的同等性ガイダンス泉に従い，そのよ うな文書が存在しない場合は，当該ガイダンスに従 うことが新たに記されている.

FDA のガイダンスでは，日本のリポソーム製剤 の開発に関するガイドラインと同様に，ICH の品 質リスクマネージメントの概念が取り入れられてお り，内容は多くないものの CQA に関する項も新た に入っている. また， 2002 年公表のドラフトガイ ダンスと同様，脂質成分の製造には有効成分と同様 の管理が求められているが，さらに，合成脂質の製 造に関してより医薬品の承認申請のための国際共通 化資料であるコモン・テクニカル・ドキュメントに 沿つた内容の記載が推奨されている。つまり，脂質 の合成過程や精製に関する詳細な記述, 出発物質, 製造工程の管理，特に重要工程と中間体の適切な管 理に関する記載が推奨されている。 


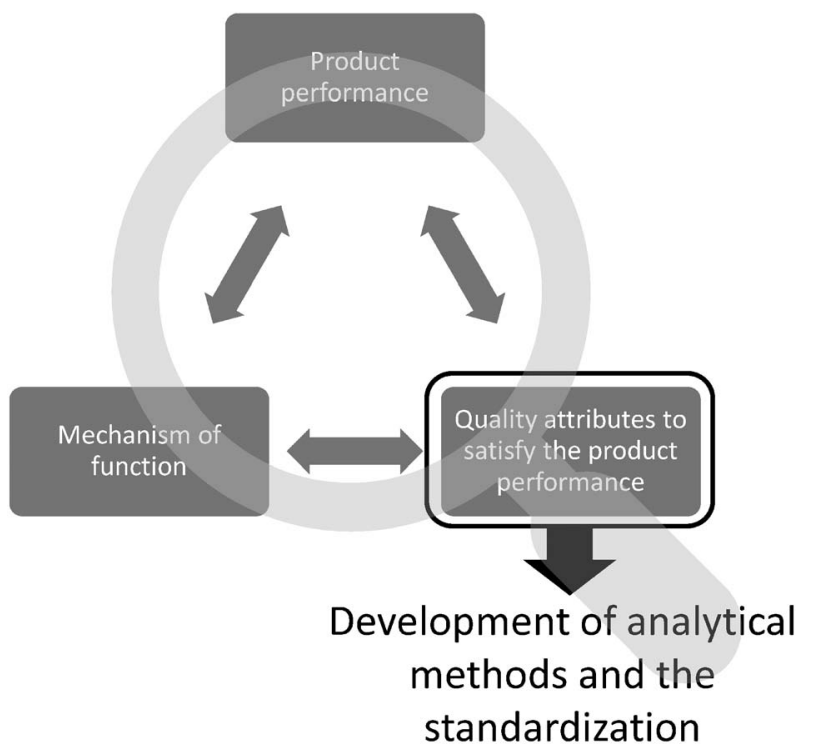

Fig. 1. Importance of Analytical Method Development and the Standardization

\section{4. ナノ DDS 製剂の品質特性解析}

ナノ DDS 製剤の構成成分の選択・処方と各成分 の機能を，目標製品品質プロファイル及び製剤特性 （例えば，放出性，標的指向性など）への影響と関 連付けるためには，製剤機能を発揮するための生体 との相互作用に関するメカニズム研究（科学的文献 を参考とすることもあるだろう)，そしてその製用 機能を叶えるための品質特性を明らかにしていくこ とが必要となる，そのためには，複雑な製剤の品質 特性を評価するための分析法の確立と標準化が重要 となる (Fig. 1)

Table 1 には，ブロック共重合体ミセル医薬品及 びリポソーム製剤の主な品質特性を示した。ブロッ ク共重合体ミセル医薬品では, 会合数や, 臨界ミセ ル濃度が主な品質特性として挙げられる。これら は，薬物の放出性やミセルの安定性等に係わる。一 方，リポソーム製剂では，脂質膜の熱力学的な特性 評価が薬物放出や安定性等に係わる品質特性と言え るであろう。

粒度分布や形態・構造，ゼー夕電位等は，ブロッ ク共重合体ミセル医薬品及びリポソーム製剤に共通 した品質特性である。また，不純物は，安全性に係 わる主要な品質特性の 1 つであり，その評価には原 薬及び製剤の不純物に関する ICH ガイドライン （ICH Q3A， Q3B， Q3C， Q3D， M7ガイドライ ン) 10-14)を参考にする。 2000 年前後に策定された
Table 1. Representative Quality Attributes

\begin{tabular}{|c|c|}
\hline Block copolymer micelle & Liposome \\
\hline \multicolumn{2}{|c|}{ Particle size distribution } \\
\hline \multicolumn{2}{|c|}{ Morphology } \\
\hline \multicolumn{2}{|c|}{ Surface charge (zeta potential) } \\
\hline \multicolumn{2}{|c|}{ In vitro release characteristics of the active substance } \\
\hline \multicolumn{2}{|c|}{ Loading efficiency of the active substances } \\
\hline \multicolumn{2}{|c|}{ Impurities (including aggregation) } \\
\hline \multicolumn{2}{|c|}{ Physical state of the encapsulated active substance } \\
\hline \multicolumn{2}{|c|}{ Surface properties (e.g., targeting ligand) } \\
\hline $\begin{array}{l}\text { Concentration dependency of } \\
\text { the nanostructure [In some } \\
\text { cases, this may be expressed } \\
\text { as critical micelle concentra- } \\
\text { tion (cmc), or critical associ- } \\
\text { ation concentration (cac).] }\end{array}$ & $\begin{array}{l}\text { Thermodynamic properties } \\
\text { of the liposome membrane }\end{array}$ \\
\hline
\end{tabular}

ICH Q3A（原薬），10ＩCH Q3B（製剂）11) 及び， ICH Q3C (医薬品の残留溶媒) ${ }^{12)}$ に加え, 昨今では, Q3D (医薬品の元素不純物) ${ }^{13)}$ が平成 29 年 4 月 1 日以降，M7 [医薬品中の DNA 反応性（変異原性） 不純物] 14) の管理が平成 28 年 1 月 15 日以降に申請 される新医薬品において適用されているため, 留意 が必要である。さらに，ナノDDS 製剤では製造工 程や保存時に生じ得るキャリア由来の不純物（凝集 体も含む）に留意が必要である.

薬物の封入量に加え, in vitro での薬物放出特性 もナノ DDS 製剤の主要な品質特性である。「ブロッ ク共重合体ミセル医薬品の開発に関する厚生労働省／ 欧州医薬品の共同リフレクションペーパー」には, 「ブロック共重合体ミセルの in vivo における安定 性を予測するために，信頼性，識別力のあるバリ デートされた in vitro 評価試験を確立し，生理的／ 臨床的に適切な溶媒中でブロック共重合体ミセルか らの有効成分の放出を測定すべきである」5) との記 載がある，個々の製剤に応じて放出特性は異なるた め，具体的な測定条件を本文書の中で示していない が，当該リフレクションペーパーの中では，識別力 のある in vitro 放出試験の設定の重要性が記されて いる（Table 2). In vivo での放出特性（つまり, 循環血中での放出特性，標的部位での放出特性）と ともに, 品質確保の観点から in vitro 放出試験が重 要な試験となる。.また，標的部位での放出特性に関 
Table 2. The Points to Consider for the Development of in Vitro Release Test

$$
\text { Main points to be considered }
$$

1. Defining the release of the active substance or polymeractive substance conjugate from carriers when in the circulation

2. Defining the release of the active substance or polymeractive substance conjugate from carriers at the targeted site of action. The proposed media should reflect the physiological environment of the formulations when in use;

For formulations that are designed to release the active substance in response to an environmental change (e.g., a $\mathrm{pH}$ change) in the target tissue or endosome, release profiles of the active substance from the carriers that reflects the physiological environment.

For formulations that are designed to release the active substance in response to a temperature change or external stimulation, release profiles of the active substances from the carriers resulting from the response to the expected temperature change or external stimulation.

3. Defining the stability on storage

しては, pH や温度などの生理的環境又は外部刺激 に応じた放出試験の設定について「リポソーム製剤 の開発に関するガイドライン」に記されている. ${ }^{6}$ In vitro 放出特性法の具体的な開発事例について本 誌上シンポジウムの他の著者の総説を参照してほし い.

\section{5. 品質特性評価法の標準化}

ナノDDS 製剤の実用化を推進するために，ナノ DDS 製剂に特徵的な品質特性を評価する試験法の 標準化や技術指針の作成が筆者らが取り組むべき課 題の 1 つである。

ナノDDS 製剤の特性において特に重要であるの が，サイズや形態である. Table 3 は，これまでに 報告されているサイズや形態の評価法を示した．光 散乱を利用した粒子径解析法には, 動的光散乱法, ナノトラッキング法，レーザー回折法がある．この うち, 動的光散乱法については, 本誌上シンポジウ ムの他の著者が詳細を記しているので，参照してほ しい. ナノトラッキング法は動的光散乱法と同様に 粒子にレーザー光を照射した際の拡散係数から粒子 径を算出する方法であるが，粒子個々の粒子径の解 析や，粒子数の計測が可能である. 同様に，個々の 粒子の画像を解析し，その形状や粒子径のばらつき を直接観察可能な手法が，画像解析法である，具体
Table 3. The Size Analysis of Nano-DDS Formulations

\begin{tabular}{|c|c|c|}
\hline Principal use & Analytical methods & Measurement principle \\
\hline \multirow{3}{*}{$\begin{array}{l}\text { Determination } \\
\text { of particle size } \\
\text { distribution }\end{array}$} & $\begin{array}{l}\text { Dynamic light scat- } \\
\text { tering }\end{array}$ & \multirow[t]{3}{*}{$\begin{array}{l}\text { Fluctuation of scattered } \\
\text { light }\end{array}$} \\
\hline & $\begin{array}{l}\text { Nano tracking } \\
\text { analysis }\end{array}$ & \\
\hline & Laser diffraction & \\
\hline \multirow[t]{2}{*}{$\begin{array}{l}\text { Acquisition of } \\
\text { image }\end{array}$} & $\begin{array}{l}\text { Atomic force } \\
\text { microscopy }\end{array}$ & $\begin{array}{l}\text { Scan of the sample sur- } \\
\text { face using nano-sized tip }\end{array}$ \\
\hline & $\begin{array}{l}\text { Electron micros- } \\
\text { copy }\end{array}$ & $\begin{array}{l}\text { Production of image of } \\
\text { the object and magnifica- } \\
\text { tion by electromagnetic } \\
\text { fields }\end{array}$ \\
\hline \multirow[t]{3}{*}{$\begin{array}{l}\text { Separation and } \\
\text { fractionation }\end{array}$} & $\begin{array}{l}\text { Centrifugal sedi- } \\
\text { mentation method }\end{array}$ & Separation by density \\
\hline & $\begin{array}{l}\text { Size exclusion } \\
\text { chromatography }\end{array}$ & $\begin{array}{l}\text { Separation by hydrody- } \\
\text { namic volume }\end{array}$ \\
\hline & $\begin{array}{l}\text { Field flow fractio- } \\
\text { nation }\end{array}$ & $\begin{array}{l}\text { Depending on the type of } \\
\text { field flow fractionation, } \\
\text { separation is based on } \\
\text { different physical proper- } \\
\text { ties such as diffusion } \\
\text { coefficient and mass }\end{array}$ \\
\hline
\end{tabular}

的には原子間力顕微鏡や電子顕微鏡法が用いられ る.さらに，サイズ毎に分離し，各分画の分離状況 を確認するとともに，分取・精製が可能な分析法も ある。このような手法には，遠心沈降法，サイズ排 除クロマトグラフィー法, 流動場分離法がある.

開発中あるいは承認取得後において，製造工程の 改良, 生産規模の拡大, 製品の安定性向上等の理由 より，製品の製造工程を変更することがある．開発 時における製法変更の同等性／同質性評価時の留意 点は，ブロック共重合体ミセル医薬品及びリポソー ム製剤に関するガイドラインで言及されている. ${ }^{5,6}$ 製造工程の変更時，開発者は，当該製品の安全性及 び有効性に有害な影響を及ぼすような変化がないこ とを示すため，関連する品質特性を評価する．製造 工程変更前後の同等性／同質性評価作業に用いる試 験の項目・内容は，製造工程変更によって生じる可 能性のある製剂の品質特性上の変化を最大限検出で きるよう，同じ品質特性項目（例えば，サイズや形 状などのそれぞれ）を評価する場合にも，それぞれ 異なる原理に基づいた物理的化学的解析方法を複数 採用して，デー夕を収集することが重要である. ${ }^{15)}$ したがって，上述した原理の異なる複数の分析評価 法を開発者が適切に使用できるように，それらの標 準化の整備が望まれる. 
日本薬局方の一般試験法には，レーザー回折法が 「3.06 レーザー回折・散乱法による粒子径測定法」 のタイトルで収載されている. ${ }^{16)}$ 当該試験法は国際 調和された手法である。一方，動的光散乱法は，参 考情報「動的光散乱法による液体中の粒子径測定法」 として掲載されており, ${ }^{17)}$ 測定法の国際調和が日米 欧三薬局方調和検討会議（Pharmacopeial Discussion Group；PDG）で進行中である. ${ }^{18)}$ さらに，サ イズ排除クロマトグラフィー法は日本薬局方一般試 験法の収載に向けて原案の議論が行われているとこ ろである。 また，サイズ排除クロマトグラフィー法 の分離に関連する用語の整備が，「クロマトグラ フィー」の国際調和においても進められている. ${ }^{19)}$ ナノDDS 製剂の画像解析が可能な手法の標準化は まだ国内で行われていないことから，筆者らは，原 子間力顕微鏡の標準化研究を進めている. ${ }^{20)}$

2016 年には FDA 主催のレギュラトリーサイエン 又会議 (Global Summit on Regulatory Science; GSRS16）が開催され，そのメインテーマに，医薬 品・医療機器・食品などのヘルスケア製品につい て，ナノテクノロジーの利用とナノテクノロジー応 用製品の標準化が取り上げられた。 ${ }^{21)}$ 筆者も組織委 員として参画し，今後の課題等を議論する機会を得 た. 各機関や規制当局から出されている標準物質や 規格文書，ガイドライン文書に関する情報は，会議 資料「Read-Ahead Material」として取りまとめら れており，上述した厚生労働省の 3 件のガイドライ ンやリフレクションペーパーも掲載されている. ${ }^{21)}$

\section{総括}

昨今，ナノ DDS 製剂には，内包薬物の多様化に より細胞内送達などのより高度な機能が求められて おり，キャリア成分の処方が複雑となることが予想 される。一方で，ナノDDS 製剤の細胞内取り込み 機能には，サイズのほか，電荷，形状，キャリアの 硬さなど 製剤の様々な品質特性が複雑に影響して いることが知られている。このように製剤特性に影 響を与える品質特性をより多角的に解析し，ナノ DDS 製剤の全体像を構築していくことが，ナノ DDS 製剤の品質管理戦略の策定や承認後も含めた 品質リスクマネージメントにおいて重要である。そ のために，本誌上シンポジウムで議論された品質特 性解析手法の開発とその標準化が有用であることは 言うまでもない．本誌上シンポジウムの総括として
本総説を閉じたい.

謝辞 本研究成果の一部は, AMED 創薬基盤 推進研究事業, AMED 医薬品等規制調和 - 評価研 究事業の支援により得られた。

利益相反＼cjkstart開示すべき利益相反はない.

\section{REFERENCES}

1) Nanotional Institute of Health Sciences (NIHS). "NIHS nanomedicines regulatory science.": 〈http://www.nihs.go.jp / drug / section $4 /$ nanomedicine_j/nano_j.html $\rangle$, cited 11 July, 2018.

2) Tatiparti K., Sau S., Kashaw S. K., Iyer A. K., Nanomaterials (Basel) , 7, 77 (2017).

3) Ministry of Health, Labour and Welfare, PFSB/ELD Notification No. 0628-1, June 28, 2010, ICH Pharmaceutical Development Q8 (R2).

4) Kozaki M., Kobayashi S., Goda Y., Okuda H., Sakai-Kato K., Chem. Pharm. Bull., 65, 218-228 (2017).

5) Ministry of Health, Labour and Welfare, PFSB/ELS Notification No. 011-1, January 10, 2014, Joint MHLW/EMA reflection paper on the development of block copolymer micelle medicinal products.

6) Ministry of Health, Labour and Welfare, PSEHB/ELD Notification No. 0328-19, March 28, 2016, Guideline for the Development of Liposome Drug Products.

7) Ministry of Health, Labour and Welfare, PSEHB/ELD Administrative Notice, March 28, 2016, Reflection paper on nucleic acids (siRNA)-loaded nanotechnology-based drug products.

8) U.S. Food and Drug Administration, "Liposome Drug Products: Chemistry, Manufacturing, and Controls; Human Pharmacokinetics and Bioavailability; and Labeling Documentation. Guidance for Industry," 2018.

9) U.S. Food and Drug Administration. "Product-Specific Guidances for Generic Drug Development.": 〈https://www.fda.gov / drugs / guidancecomplianceregulatoryinfor mation/guidances/ucm075207.htm $\rangle$, cited 11 
July, 2018.

10) Ministry of Health, Labour and Welfare, PMSB/ELD Notification No. 1216001, December 16, 2002, ICH Impurities in New drug Substances Q3A(R2).

11) Ministry of Health, Labour and Welfare, PMSB/ELD Notification No. 0624001, June 24, 2003, ICH Impurities in New drug Products Q3B (R2).

12) Ministry of Health, Labour and Welfare, PMSB/ELD Notification No. 307, March 30, 1998, ICH Impurities: Guideline for Residual Solvents Q3C (R3).

13) Ministry of Health, Labour and Welfare, PFSB/ELD Notification No. 0930-4, September 30, 2015, ICH Guideline for Elemental Impurities Q3D.

14) Ministry of Health, Labour and Welfare, PSEHB / ELD Notification No. 1110-3, November 10, 2015, ICH Assessment and Control of DNA reactive (Mutagenic) impurities in Pharmaceuticals to Limit Potential Carcinogenic Risk M7.

15) Ministry of Health, Labour and Welfare, PFSB/ELD Notification No. 0426001, April
26, 2005, ICH Note for Guidance on Comparability of Biotechnological / Biological Products Subject to Changes in their Manufacturing Process Q5E.

16) Ministry of Health, Labour and Welfare, "Supplement I to The Japanese Pharmacopoeia Seventeenth Edition," 2017.

17) Ministry of Health, Labour and Welfare, "The Japanese Pharmacopoeia Seventeenth Edition," 2016.

18) Pharmaceuticals and Medical Devices Agency. "Pharmacopoeial Discussion Group Meeting.": 〈http://www.pmda.go.jp/files/000212 581.pdf $\rangle$, cited 11 July, 2018.

19) Japanese Pharmacopoeial Forum, 26, 358-389 (2017).

20) Takechi-Haraya Y., Goda Y., Sakai-Kato K., Anal. Bioanal. Chem., 410, 1525-1531 (2018).

21) U.S. Food and Drug Administration. "Global Summit on Regulatory Science (GSRS16).”: 〈http: // www.fda.gov / AboutFDA / Centers Offices / OC / OfficeofScientificandMedicalPro grams/NCTR/WhatWeDo/ucm488022.htm $\rangle$, cited 11 July, 2018. 